\title{
New fish species added to the ichthyofauna of Laguna Ojo de Liebre, Baja California Sur, México
}

\author{
Laura CIVICO-COLLADOS, Jorge A. ROSALES-CASIÁN \\ Cite this article as: \\ Cívico-Collados, L., Rosales-Casián, J.A. (2021). New fish species added to the ichthyofauna of Laguna Ojo de Liebre, Baja California Sur, México. \\ Aquatic Research, 4(4), 343-350. https://doi.org/10.3153/AR21029
}

Centro de Investigación Científica y de Educación Superior de Ensenada, B.C. (CICESE). Departamento de Ecologia Marina, División de Oceanología. Carretera Ensenada-Tijuana No. 3918, Zona Playitas, C.P. 22860, Ensenada, Baja California, México

ORCID IDs of the author(s): L.C.C. 0000-0003-0572-3702 J.A.R.C. 0000-0002-5546-5791

Submitted: 04.01.2021

Revision requested: 17.03.2021

Last revision received: 11.05 .2021

Accepted: 11.05.2021

Published online: 13.06 .2021

Correspondence:

Jorge A. ROSALES-CASIÁN

E-mail: jrosales@cicese.mx

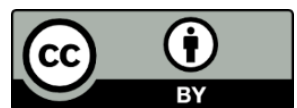

(C) 2021 The Author(s)

Available online at

http://aquatres.scientificwebjournals.com

\begin{abstract}
The Laguna Ojo de Liebre (Scammon's lagoon) is the iconic sanctuary of the Pacific gray whale and belongs to the El Vizcaino Biosphere Reserve in Baja California, México. From June 2015 to August 2016, six seasonal visits were conducted on the ichthyofauna in seven sites of the lagoon. By diving, trapping, hook \& line, and gillnet commercial fishing, a total number of 39 fish species was identified belonging to 25 families. In this study a total number of eight fish species is added to the first two existing 20-year-old lists: the Gymnothorax mordax (Ayres, 1859), Apogon sp. Pomacanthus zonipectus (Gill, 1862), Balistes polylepis (Steindachner, 1876), Pareques viola (Gilbert 1898), Caranx sp., Sphoeroides lobatus (Steindachner, 1870), and the Icelinus sp. During 2015-2016, two anomalous events warmed the lagoon, and possibly, it contributed to the fish species movement from the adjacent tropical or subtropical zones. Ichthyofauna from Laguna Ojo de Liebre is reported here before the installation of reef modules as a refuge for red lobster and fish aggregation.
\end{abstract}

Keywords: Species occurrence, Scammon's lagoon, The Blob, El Niño, Warming conditions 


\section{Introduction}

Laguna Ojo de Liebre (Scammon's lagoon) with 57,100 hectares is a coastal lagoon on the Pacific of Baja California Sur (Mexico) and considered of great importance for conservation since it serves as refuge, feeding and breeding area for fish species (Acevedo-Cervantes, 1997). As a sanctuary for the gray whale, the lagoon has been declared a World Heritage Site by UNESCO as part of the Man and Biosphere program (De la Cruz-Agüero, Gómez, and Arellano-Martinez, 1996). Such protected areas are scarce in the Pacific of Baja California and, therefore, essential as a nursery for commercial fish species or of ecological interest due to sparsely populated areas with low development pressure (Rosales-Casián, 1997). This lagoon is of particular interest as a local cooperative of Guerrero Negro, B.C.S. (Mexico) will install artificial reefs made with concrete $(1.5 \mathrm{~m}$ long, $1.15 \mathrm{~m}$ wide, and $0.25 \mathrm{~m}$ high) as a refuge for lobster and fish for commercial capture.

Several studies have been carried out in Laguna Ojo de Liebre to characterize longshore sediments transport (Marinone, 1982; Zamora-Salvador, 2015), environmental conditions (Alvarado et al., 1986; Álvarez-Borrego and Granados-Guzman, 1992; Gutiérrez de Velasco, 2000; Rodríguez-Padilla, 2013), commercial bivalves (Arellano-Martinez et al., 2004; Hernández-Olalde et al., 2007; Quiñones-Arreola, 2003), and the green turtle population Chelonia mydas status (Hernández-Cruz, 2013). Despite it is importance as a refuge and feeding area for different organisms, there are few studies on the fish species that live there. De la Cruz-Agüero, Gómez, and Arellano-Martinez (1996) published a first systematic list of fish species from Ojo de Liebre and Guerrero Negro lagoons, and Acevedo-Cervantes (1997) characterized the community of Laguna Ojo de Liebre, concluding that it is a low diversity site compared to other lagoon systems in Mexico, with small size specimens, and seasonally influenced by the entry of species from the adjacent Sebastian Vizcaino Bay to complete their life cycle.

Motivated by the planned artificial reef deployment by a local cooperative of Laguna Ojo de Liebre, the present study aimed to identify the fish species inhabitants at sites considered suitable for artificial reef enhancement, for future comparisons of the fish community after installation.

\section{Material and Methods}

\section{Study Area}

Laguna Ojo de Liebre is located at the Pacific half of Baja California peninsula, close to the town of Guerrero Negro, Baja California Sur, Mexico (Figure 1), between $27^{\circ} 36^{\prime}$ and $27^{\circ} 55^{\prime}$ North latitude and $113^{\circ} 55^{\prime}$ and $114^{\circ} 19^{\prime}$ West latitude. It is part of the Ojo de Liebre lagoon complex comprised of Laguna Manuela (north), Laguna Guerrero Negro (middle), and to the south the Laguna Ojo de Liebre (Eberhardt, 1966). The lagoon area is $480 \mathrm{~km}^{2}, 40 \mathrm{~km}$ length, and a mean of 6 $\mathrm{km}$ width. It is connected to the Sebastián Vizcaino Bay through a $3.7 \mathrm{~km}$ wide of mouth and has four main islands in its interior: Conchas, Brosas, Piedras, and Choya. The lagoon topography is shallow (average 5-6 meters depth) and includes a relatively deep channel (up to $30 \mathrm{~m}$ maximum depth) surrounded by intertidal flats (Rodríguez-Padilla, 2013).

Tide is an important component in the Laguna Ojo de Liebre dynamics, with an interval from 1.20 to $2.70 \mathrm{~m}$, and predominant currents up to $1.18 \mathrm{~m} / \mathrm{s}$ (Gutiérrez de Velasco, 2000). Maximum tidal speeds are reached during rising and falling, weaker in the ridges and valleys, and most intense and turbulent currents appear at mouth and channels (Zamora-Salvador, 2015).

The present study was carried out in a section with an influence of seawater from the adjacent Sebastian Vizcaino Bay during high tide (Rodríguez-Padilla, 2013). Seven sites were chosen after the fishermen experience as the best sites for catching lobster and fish, and therefore feasible in depth for the artificial reefs deployment (Table 1), and all the work carried out was fully supported by the staff of the Cooperative "Luis Gómez Z." of Guerrero Negro, B.C.S. (Mexico).

\section{Ojo de Liebre lagoon Fish Collections and observations}

The fish survey began in June 2015 (spring), followed by September (summer) and November (autumn) 2015, and February (winter), May (spring), and August (summer) 2016, for a total of six seasonal visits. We consider winter from January to March, spring (April-June), summer (July-September) and autumn (October-December).

Trap collections: Because the lagoon is a marine reserve, two fish monitoring methods were selected to avoid disturbing the bottom; we used commercial traps and underwater diving visual census during two days. The traps were built by the fishermen with pieces of wire mesh covered with a plastic layer, dimensions $88 \mathrm{~cm}$ wide, $122 \mathrm{~cm}$ long, and $43 \mathrm{~cm}$ high, with an entrance $30 \mathrm{~cm}$ in diameter and a $7 \mathrm{~cm}$ mesh. The traps were prepared with buoys, ropes, and sardines as bait. A total of six sites within the lagoon were selected for fish collections with traps because they are usually fishing spots with the possibility of improvement with artificial reefs: El Borbollón, El Conchalito, La Ventana, Isla Concha, El Esterito, and Carros Viejos (Figure 1). 
Table 1. Monitoring sites and coordinates in the Laguna Ojo de Liebre, BCS, Mexico, 2015-2016.

\begin{tabular}{lccll}
\hline Sampling sites & North latitude & West longitude & Survey & Substrate \\
\hline El Borbollón & $27^{\circ} 51^{\prime} 28.14^{\prime \prime}$ & $114^{\circ} 14^{\prime} 2.40^{\prime \prime}$ & Diving / Traps & $\begin{array}{l}\text { Rocky / } \\
\text { Sandy }\end{array}$ \\
El Conchalito & $27^{\circ} 47^{\prime} 1.14 ”$ & $114^{\circ} 16^{\prime} 28.68^{\prime \prime}$ & Diving / Traps & Limestone \\
La Ventana & $27^{\circ} 47^{\prime} 18.04 ”$ & $114^{\circ} 18^{\prime} 11.40^{\prime \prime}$ & Diving / Traps & Limestone \\
La Ventanita & $27^{\circ} 46^{\prime} 48.18^{\prime \prime}$ & $114^{\circ} 17^{\prime} 7.62^{\prime \prime}$ & Diving & Sandy \\
Isla Concha & $27^{\circ} 49^{\prime} 15.70^{\prime \prime}$ & $114^{\circ} 13^{\prime} 54.40^{\prime \prime}$ & Traps & Shell / Sandy \\
Carros Viejos & $27^{\circ} 50^{\prime} 26.80^{\prime \prime}$ & $114^{\circ} 16^{\prime} 59.80^{\prime \prime}$ & Traps & Sandy \\
El Esterito & $27^{\circ} 48^{\prime} 24.10^{\prime \prime}$ & $114^{\circ} 17^{\prime} 49.50^{\prime \prime}$ & Traps & Sandy \\
\hline
\end{tabular}

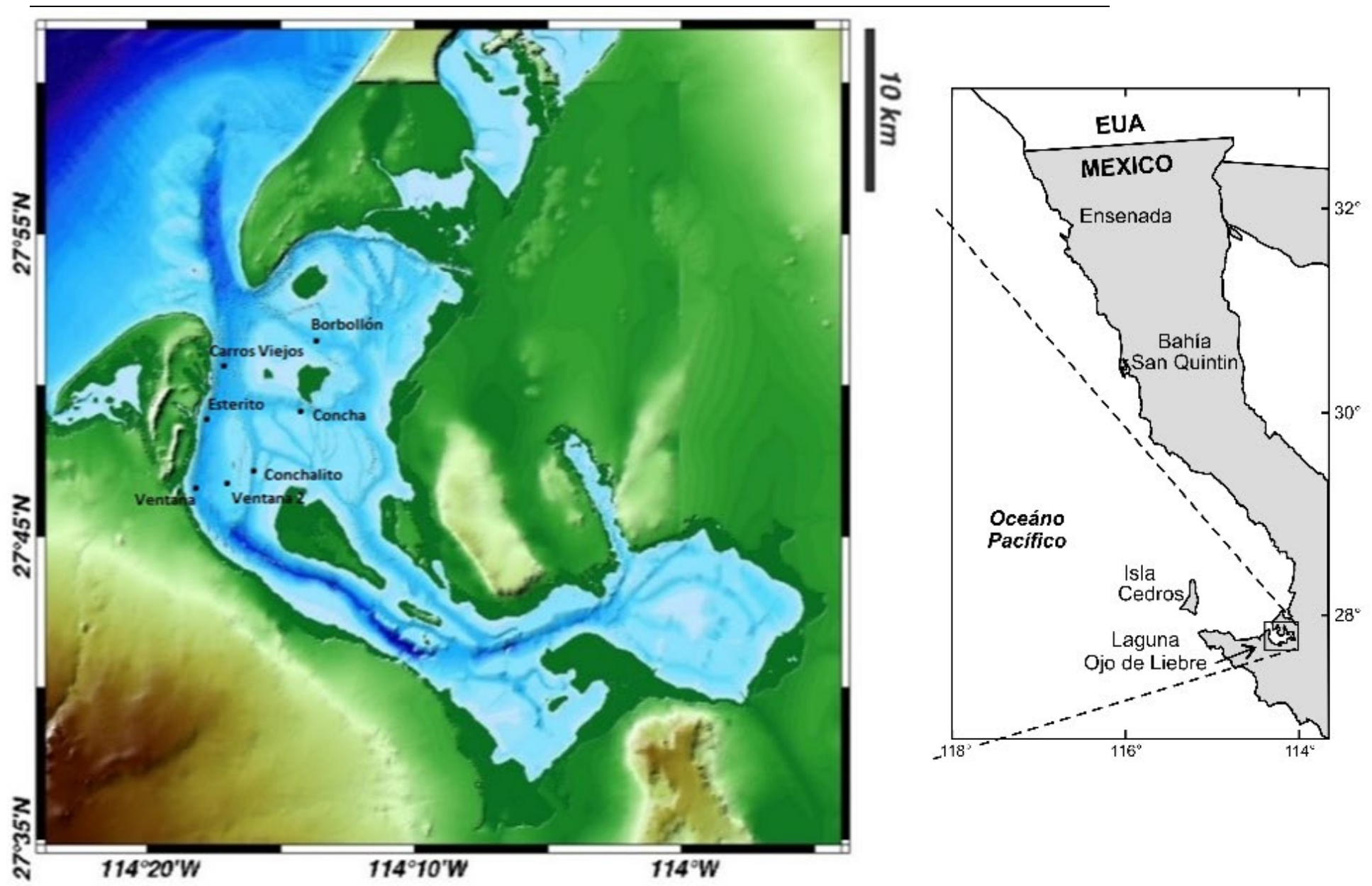

Figure 1. Localization of the Laguna Ojo de Liebre, BCS, Mexico, and sampling sites. 
For the seasonal catch of fish, four traps as repetitions were launched separated by $50-100 \mathrm{~m}$ in each selected site, and remained at the bottom during 45 minutes following the local fishermen's technique (30 to 60 minutes); their total length (TL, mm) of captured fish was measured, intervals for each fish species are reported here.

Diving observations: Because diving is limited in time by the tidal current, four sites were selected: El Borbollón, El Conchalito, La Ventana, and a new site La Ventanita. We select the neap low tide from the monitoring day to avoid strong tidal currents. In each visited site, three diving transects in parallel of $30 \mathrm{~m}$ long, $2 \mathrm{~m}$ wide, $2 \mathrm{~m}$ high, and separated by $5 \mathrm{~m}$ between transects were made (Freiwald et al., 2015). Each transect was performed in a maximum time of seven minutes. One diver identified the fish species, determined the fish counts of each species and logged the approximate size. A second diver photographed the fish species. A third diver photographed the lagoon bottom and invertebrates. Trap collections and underwater diving census were carried out on boats separately in order to not interfere.

During our lagoon visits and the periods between the trap catches, fishing with hook-and-line was done, and also fish from commercial catches with gillnets also were identified, and added to the list without their lengths.

Fish species identification: All the species were identified using the keys for the Pacific of Baja California, Mexico, and California, USA (Miller and Lea, 1972), and for warm fish species, the work of Humann and Deloach (2004) was used. Arrangement of the classes, orders, and families follows the work of Nelson (2006) and Fricke et al., (2021). The biogeographic affinities of the fish species are presented according to Horn, Allen, and Lea (2006).

\section{Results and Discussion}

During the sampling period in Laguna Ojo de Liebre (June 2015 to August 2016), a total of 138 traps launches was made, for a total capture time of 138 hours trap and 48 minutes. Regarding the underwater visual census, a total of 72 transects was made for 360 minutes of diving.

The taxonomic list in Laguna Ojo de Liebre included a total number of 39 fish species belonging to 25 families. Underwater visual census showed 28 fish species, and traps showed 13 fish species, with nine common species in both methods (Table 2). Hook-and-line captured seven of the fish species. From a total of 21 species identified in the commercial catch, six species were not found with traps and diving (Table 2). A total of 31 species were teleost, and eight were elasmobranchs
(Table 2). A total of 2,724 fish was counted, 893 individuals in the trap collections, and 1,179 individuals observed during diving. In the first ichthyofaunal list of Laguna Ojo de Liebre, De la Cruz Agüero et al., (1996) identified 59 species from 36 families, however they included the adjacent Guerrero Negro Lagoon without discriminating the fish species from each lagoon, and used five collection gears with hook-and-line as the only coincident with the present study. In the second study by Acevedo-Cervantes (1997) he also identified 59 fish species and none of the three collecting gears used coincided with those of the present study; a species not included in the first study and mentioned in the second was the kelp bass Paralabrax clathratus, while in the present study this species was collected frequently in traps and observed in diving.

In the present study, families that contributed with the largest number of individuals were Sparidae with 1,227 individuals (one species), Serranidae with 1,165 individuals (three species), and Labridae with 153 individuals (two species). Most abundant fish species were the Pacific porgy, Calamus brachysomus (Lockington, 1880) with 1,227 individuals (45.1\%), the barred sand bass, Paralabrax nebulifer (Girard, $1854)$ with 768 individuals $(28.2 \%)$, the spotted sand bass, Paralabrax maculatofasciatus (Steindachner, 1868) with 302 individuals $(11.1 \%$, ) the rock wrasse, Halichoeres semicinctus (Ayres, 1859) with 142 individuals (5.2\%), and the kelp bass, Paralabrax clathratus (Girard, 1854) with 95 individuals $(3.5 \%)$, which together contributed $93 \%$ of the total abundance (Table 2).

Elasmobranchs Dasyatis dipterura (Jordan \& Gilbert, 1880) (130 cm TL) and Zapteryx exasperata (Jordan \& Gilbert, 1880) (100 cm TL) were the bigger fish, while larger teleost was the California moray Gymnothorax mordax (Ayres, 1859) (98 cm TL), the kelp bass $P$. clathratus (65 cm TL), and the broomtail grouper Mycteroperca xenarcha Jordan, 1888 with $60 \mathrm{~cm}$ TL (Table 2). Small fish were the California killifish Fundulus parvipinnis Girard, 1854, the spotted sand bass $P$. maculatofasciatus, the barred sand bass $P$. nebulifer (all $4 \mathrm{~cm} \mathrm{TL}$ ), and the cardenalfish Apogon sp., the rock wrasse $H$. semicinctus, and the bullseye puffer Sphoeroides annulatus (Jenyns, 1842) with $5 \mathrm{~cm}$ TL (Table 2).

One fish species showed a cold affinity to the Aleutian Province, seven species with northern distribution to the Oregon Province, 26 species show affinity to the Province of San Diego (68.4\%), and three to the Cortez Province. The major percentage (86.8\%), comprising 32 species, that extends south to the Provinces of Cortez, Mexican province, or to Panamian Province. (Table 2). 
Table 2. Fish species from Laguna Ojo de Liebre, BCS, Mexico, 2015-2016; lengths (cm); H\&L: hook and line; CF: commercial fishing; BA: Biogeographic affinity. Distribution by provinces after Horn et al. (2006): AP: Aleutian province; OR: Oregonian province; SD: San Diego province; Cortez province; MX: Mexican province; PP: Panamian province.

\begin{tabular}{|c|c|c|c|c|c|c|c|c|c|}
\hline \multirow{2}{*}{$\begin{array}{l}\text { Class/Order } \\
\text { Chondrichthyes }\end{array}$} & \multirow[t]{2}{*}{ Family } & \multirow[t]{2}{*}{ Fish species } & \multicolumn{2}{|c|}{ Number Dive } & \multicolumn{2}{|c|}{ Trap Size (cm) } & \multirow[t]{2}{*}{ H\&L } & \multirow[t]{2}{*}{$\mathbf{C F}$} & \multirow[t]{2}{*}{ BA } \\
\hline & & & & & & & & & \\
\hline Heterondontiformes & Heterodontidae & Heterodontus francisci (Girard, 1855) & 11 & $\mathrm{X}$ & $X$ & $30-80$ & & $\mathrm{X}$ & OR-CZ \\
\hline Torpediniformes & Narcinidae & Narcine entemedor Jordan and Starks, 1895 & 1 & $\mathrm{X}$ & & 75 & & & SD-PP \\
\hline Rhinopristiformes & Rhinobatidae & Pseudobatos leucorhynchus (Günther, 1867) & 4 & $\mathrm{X}$ & & $70-76$ & & & CZ-PP \\
\hline \multirow[t]{2}{*}{ Rajiformes } & & Pseudobatos productus (Ayres, 1854) & 2 & $\mathrm{X}$ & & $60-70$ & & $\mathrm{X}$ & SD-MX \\
\hline & & Zapteryx exasperata (Jordan \& Gilbert, 1880) & 2 & $\mathrm{X}$ & & 100 & & $\mathrm{X}$ & SD-MX \\
\hline \multirow[t]{3}{*}{ Myliobatiformes } & Urotrygonidae & Urobatis halleri (Cooper, 1863) & 13 & $\mathrm{X}$ & $\mathrm{X}$ & $20-30$ & & & SD-PP \\
\hline & & Urobatis maculatus Garman, 1913 & 2 & $\mathrm{X}$ & & 40 & & & $\mathrm{SD}-\mathrm{CZ}$ \\
\hline & Dasyatidae & Hypanus dipterurus (Jordan \& Gilbert, 1880) & 2 & $\mathrm{X}$ & & 130 & & & SD-PP \\
\hline \multicolumn{10}{|l|}{ Osteichthyes } \\
\hline Anguilliformes & Muraenidae & Gymnothorax mordax (Ayres, 1859) & 1 & & $\mathrm{X}$ & 98 & & & SD \\
\hline Cyprinodontiformes & Fundulidae & Fundulus parvipinnis Girard, 1854 & 29 & $\mathrm{X}$ & & $4-6$ & & & SD \\
\hline Gasterosteiformes & Syngnathidae & Hippocampus ingens Girard, 1858 & 4 & $\mathrm{X}$ & & $15-20$ & & & SD-PP \\
\hline \multirow[t]{2}{*}{ Scorpaeniformes } & Scorpaenidae & Scorpaena guttata Girard, 1854 & & & & & $\mathrm{X}$ & $\mathrm{X}$ & SD-CZ \\
\hline & Cottidae & Icelinus sp. & 1 & $\mathrm{X}$ & & 10 & & & \\
\hline \multirow[t]{21}{*}{ Perciformes } & Epinephelidae & Mycteroperca xenarcha Jordan, 1888 & 2 & $\mathrm{X}$ & & 60 & $\mathrm{X}$ & $\mathrm{X}$ & SD-PP \\
\hline & Serranidae & Paralabrax clathratus (Girard, 1854) & 95 & $\mathrm{X}$ & $\mathrm{X}$ & $10-65$ & $\mathrm{X}$ & $\mathrm{X}$ & OR-SD \\
\hline & & Paralabrax maculatofasciatus (Steindachner, 1868) & 302 & $\mathrm{X}$ & $\mathrm{X}$ & $4-42$ & $\mathrm{X}$ & $\mathrm{X}$ & OR-CZ \\
\hline & & Paralabrax nebulifer (Girard, 1854) & 768 & $\mathrm{X}$ & $\mathrm{X}$ & $4-53$ & $\mathrm{X}$ & $\mathrm{X}$ & OR-MX \\
\hline & Apogonidae & Apogon sp. & 10 & $\mathrm{X}$ & & $5-7$ & & & SD \\
\hline & Carangidae & Caranx sp. & 1 & $\mathrm{X}$ & & 70 & & & SD-PP \\
\hline & & Caranx caninus Günther, 1867 & & & & & & $\mathrm{X}$ & SD-PP \\
\hline & Haemulidae & Anisotremus davidsonii (Steindachner, 1875) & 40 & $\mathrm{X}$ & $\mathrm{X}$ & $20-33$ & & $\mathrm{X}$ & SD-CZ \\
\hline & Sparidae & Calamus brachysomus (Lockington, 1880) & 1227 & $\mathrm{X}$ & $\mathrm{X}$ & $9-47$ & $\mathrm{X}$ & $\mathrm{X}$ & SD-PP \\
\hline & Sciaenidae & Atractoscion nobilis (Ayres, 1860) & 1 & & $X$ & 74 & & $\mathrm{X}$ & $\mathrm{AP}-\mathrm{CZ}$ \\
\hline & & Cynoscion parvipinnis Ayres, 1861 & & & & & & $\mathrm{X}$ & SD-CZ \\
\hline & & Cynoscion xanthulus Jordan \& Gilbert, 1882 & & & & & & $\mathrm{X}$ & CZ-MX \\
\hline & & Menticirrhus undulatus (Girard, 1854) & & & & & & $\mathrm{X}$ & SD-PP \\
\hline & & Pareques viola (Gilbert, 1898) & 8 & $\mathrm{X}$ & & $5-8$ & & & SD-PP \\
\hline & & Roncador stearnsii (Steindachner, 1875) & & & & & & $\mathrm{X}$ & SD \\
\hline & & Umbrina roncador Jordan and Gilbert, 1882 & & & & & & $\mathrm{X}$ & SD-CZ \\
\hline & Pomacanthidae & Pomacanthus zonipectus (Gill, 1862) & 1 & $\mathrm{X}$ & & 25 & & & $\mathrm{CZ}$ \\
\hline & Pomacentridae & Hypsypops rubicundus (Girard, 1854) & 2 & $\mathrm{X}$ & & 25 & & & SD-CZ \\
\hline & Labridae & Halichoeres semicinctus (Ayres, 1859) & 142 & $\mathrm{X}$ & & $5-26$ & & & SD-CZ \\
\hline & & Semicossyphus pulcher (Ayres, 1854) & 11 & & $X$ & $33-48$ & & $\mathrm{X}$ & OR-CZ \\
\hline & Blenniidae & Hypsoblennius gentilis (Girard, 1854) & 1 & $\mathrm{X}$ & & 7 & & & $\mathrm{SD}-\mathrm{CZ}$ \\
\hline \multirow[t]{2}{*}{ Pleuronectiformes } & Paralichthyidae & Paralichthys californicus (Ayres, 1859) & 1 & $\mathrm{X}$ & & 11 & & $\mathrm{X}$ & OR-SD \\
\hline & Pleuronectidae & Pleuronichthys guttulatus (Girard, 1856) & 1 & $\mathrm{X}$ & & 10 & & $\mathrm{X}$ & OR-CZ \\
\hline \multirow[t]{3}{*}{ Tetraodontiformes } & Balistidae & Balistes polylepis Steindachner, 1876 & 4 & & $\mathrm{X}$ & $24-31$ & & $\mathrm{X}$ & SD-CZ \\
\hline & Tetraodontidae & Sphoeroides annulatus (Jenyns, 1842) & 31 & $\mathrm{X}$ & $\mathrm{X}$ & $5-38$ & & & SD-PP \\
\hline & & Sphoeroides lobatus (Steindachner, 1870) & 4 & $\mathrm{X}$ & $\mathrm{X}$ & $6-34$ & & & SD-PP \\
\hline
\end{tabular}

Laguna Ojo de Liebre is influenced by tidal currents and oceanic events such as El Niño/La Niña (Gutierrez de Velasco, 2000). During our monitoring in 2015-2016, the tidal currents limited the time of the diving census, and the selected neap lowest tides allowed only one hour for the transects. This lagoon is adjacent to Vizcaino Bay which has been considered a center of fish larvae production (Moser et al., 1993), and during El Niño events there was a high proportion of tropical and subtropical taxa that contributed to the highest abundance of fish larvae (Jimenez-Rosenberg et al., 2007).

The lagoon was influenced by the warm water "The Blob" formed in the Gulf of Alaska in 2013 that extended south to 2016, and El Niño 2015-2016 (Dorantes-Gilardi and Rivas, 2019). The El Niño was intense with anomalies of more than $2{ }^{\circ} \mathrm{C}$ for the Eastern Pacific at Northern Hemisphere, began in January 2015 up to winter 2016 to weaken at Spring and to 
finish in June (NOAA's El Niño, available at http://www.elnino.noaa.gov/, last accessed 10 August, 2019).

The fish monitoring was focused on potential sites for the deployment of artificial reefs, and this may explain the lesser number of registered fish species compared to other studies which monitored a larger area of the lagoon identifying a total number of 59 fish species (De la Cruz-Agüero, Gómez, and Arellano-Martinez, 1996). Notably, in the present study, a total of eight new species are added to the two systematic lists of fish species in the Laguna Ojo de Liebre: The California moray (G. mordax), the sculpin (Icelinus sp.), the cardenalfish (Apogon sp.), the jack (Caranx sp.), the gungo highhat (Pareques viola), the Cortez angelfish (Pomacanthus zonipectus), the finescale triggerfish (Balistes polylepis), and the longnose puffer (Sphoeroides lobatus). In the present study, of the eight added fish species, six were identified by diving, and two collected with traps: the California moray, and the finescale triggerfish.

The species-specific zoogeographic affinities in the present study were grouped into five zoogeographic provinces: Aleutian, Oregonian, San Diego, Cortez, Mexican and Panamian (Horn, Allen, and Lea, 2006); species considered from temperate zones are represented by those distributed in the province of San Diego and in this study made up 68.4\%; those from cold environments (Oregonian and Aleutian provinces) accumulated $23.7 \%$, while three species $(7.9 \%)$ presented subtropical and tropical affinity, only. However, of the total species, $86.8 \%$ have a southern distribution corresponding to the subtropical and tropical environment, from the provinces of Cortez, Mexican to Panamian. Those species affinities can be attributed to the southern boundary of the Southern California Current and the transition to the subtropical province at the latitude $\left(27^{\circ} 5^{\prime} 43^{\prime \prime} \mathrm{N}, 115^{\circ} 08^{\prime} 15^{\prime}\right.$ ' W) of Punta Eugenia (Hubbs, 1960, Jiménez-Rosenberg et al., 2007). The presence of a warming events that began at end of 2013 and finished in 2016 (Dorantes and Rivas, 2019; Robinson, 2016) may have caused movements of fish from the tropical or subtropical zone to the Laguna Ojo de Liebre, like the Cortez Angelfish, the gungo highhat, and the jack which contributed to the increased list of fish species.

Although the artificial reef modules will be built and deposited in the bottoms of the Ojo de Liebre lagoon as a refuge for red lobster, they present an excellent opportunity to study for the fish aggregation that take refuge in the structures.

\section{Conclusion}

This new study on the ichthyofauna of Laguna Ojo de Liebre identified 39 fish species, with eight new species that are added to the first lists of fish in the lagoon. Combining of traps and mainly diving was essential to identify the new species, also as non-destructive methods it avoided the alteration of the lagoon bottom. The presence of two warming events (The Blob and El Niño) during the 2015-2016 study possibly promoted the movement of subtropical or tropical species to the North. This work will be compared with the next survey on the possible changes when a local cooperative installs the artificial reef modules in the lagoon.

\section{Compliance with Ethical Standard}

Conflict of interests: The authors declare that for this article they have no actual, potential or perceived conflict of interests.

Ethics committee approval: This study was conducted in accordance with ethics committee procedures of animal experiments.

Funding disclosure: Funds for this research was provided from the project of Center for Scientific Research and Higher Education of Ensenada (CICESE) headed by Jorge A. Rosales-Casián "Baseline study of fish community structure in sites for artificial reef deployment in Laguna Ojo de Liebre, BCS". Thanks to CONACYT-Mexico for the graduate scholarship to Laura Civico-Collados to be able to carry out her master's studies.

Acknowledgments: Our special thanks to Oc. Javier Lugo-Yuriar and Mr. Marco Gómez-Romero, Presidents of Cooperative "Luis Gómez Z." from Guerrero Negro, B.C.S; the support they provided us along with their staff was integral, from processing permits to enter the salt company area, and the boats, outboard motors, traps, gas and the effort on board to make the monitoring successful. Thanks to many graduate students who participated as support in our monitoring trips: Anahí, Marianne, Schery, Maribel, Rigo, Mariana, Jorge Jr., Rodrigo, Abigail, Gonzalo, Arturo, and Violeta.

\section{Disclosure: -}




\section{References}

Acevedo-Cervantes, A. (1997). Caracterización ecológica de la comunidad íctica de la Laguna Ojo de Liebre, B.C.S, México. La Paz, Baja California: Instituto Politécnico Nacional, Centro Interdisciplinario de Ciencias Marinas (CICIMAR). Master's thesis, 108p.

Alvarado, B.J., Galindo, J., Iwadane, G.M., Migoya, K.R., Vázquez, M. (1986). Evaluación de los parámetros ambientales y su relación con la distribución y movimientos de la ballena gris Eschrichtius robustus Lacepede 1804 en la Laguna Ojo de Liebre, B.C.S., México. Ciencia Pesquera IPN, $5,33-49$.

Álvarez-Borrego, S., Granados-Guzmán, A. (1992). Variación espacio-temporal de temperaturas en un hábitat de invierno de la ballena gris: Laguna Ojo de Liebre. Ciencias Marinas, 18(1), 151-165.

https://doi.org/10.7773/cm.v18i1.872

Arellano-Martínez, M., Ceballos-Vázquez, B.P., VillalejoFuerte, M., García-Domínguez, F., Elorduy-Garay, J.F., Esliman-Salgado, A., and Racotta, I.S. (2004). Reproduction of the lion's paw scallop Nodipecten subnodosus Sowerby, 1835 (Bivalvia: Pectinidae) from Laguna Ojo de Liebre, BCS, México. Journal of Shellfish Research, 23(3), 723-720.

De La Cruz-Agüero, J.D., Gómez, V.M.C., Arellano-Martinez, M.A. (1996). Lista sistemática de los peces marinos de las lagunas Ojo de Liebre y Guerrero Negro, BCS y BC, México. Ciencias Marinas, 22(1), 111-128.

Dorantes-Gilardi, M., Rivas, D. (2019). Effects of the 2013-2016 Northeast Pacific warm anomaly on physical and biogeochemical variables off northwestern Baja California, derived from a numerical NPZD ocean model. Deep-Sea Res. II. Top. Stud. Oceanography. 169-170, 104668.

https://doi.org/10.1016/j.dsr2.2019.104668

Eberhardt, R.L. (1966). Coastal geographical features of Laguna Guerrero Negro. The California Geographer, 7, 2935.

Freiwald, J., Wisniewski, C., Wehrenberg M., Shulman, C., Dawson, C. (2015). Reef check California instruction manual: a guide to rocky reef monitoring. Reef Check Foundation, Pacific Palisades, California, 152p.

Fricke, R., Eschemeyer, W.N., Van der Laan, R. (2021). Eschmeyer's Catalog of Fishes: Genera, species, references. http://researcharchive.calacademy.org/research/ichthyology/catalog/fishcatmain.asp (accessed 09. 05.2021).

Gutiérrez de Velasco, G. (2000). Análisis de la circulación y las condiciones físicas de la Laguna Ojo de Liebre, B.C.S. con relación a la mortandad de Tortugas Marinas durante diciembre de 1997. Informe final para la Compañía Exportadora de Sal, ESSA. México, 44p.

Hernández-Olalde, L.N., García-Domínguez, F.I., Arellano-Martínez, M.A., Ceballos-Vázquez, B.A.P. (2007). Reproductive cycle of the pearl oyster Pteria sterna (Pteriidae) in the Ojo de Liebre lagoon, BCS, México. Journal of Shellfish Research, 26(2), 543-548.

https://doi.org/10.2983/07308000(2007)26[543:RCOTPO]2.0.CO;2

Hernández-Cruz, G. (2013). Análisis de la captura diurna y nocturna y estado de la población de tortuga prieta (Chelonia mydas) en Laguna Ojo de Liebre, Baja California Sur: 20092012. Ensenada, Baja California: Centro de Investigación Científica y de Educación Superior de Ensenada, B.C. (CICESE), Master's thesis, 84p.

Humann, P., Deloach, N. (2004). Reef fish identification: Baja to Panama. Jacksonville, Florida: New World Publications, 343p. ISBN: 9781878348388.

Horn, M.H., Allen, L.G., Lea, R.N. (2006). Biogeography. In L.G. Allen, D.J. Pondella \& M.H. Horn (Eds.), The ecology of marine fishes. California and adjacent waters (p. 325). Berkeley, CA: University of California Press. ISBN13: $978-0520246539$

https://doi.org/10.1525/california/9780520246539.003.0001

Hubbs, C.L. (1960). The marine vertebrates of the outer coast. Symposium The Biogeography of Baja California and adjacent seas. Systematic Zoology, 9(3-4), 134-147. https://doi.org/10.2307/2411962

Jiménez-Rosenberg, S.P.A., Saldierna-Martinez, R.J., Aceves-Medina, G., Cota-Gómez, V.M. (2007). Fish larvae in Bahía Sebastián Vizcaino and the adjacent oceanic region, Baja California, México. Checklist, 3(3), 204-223. https://doi.org/10.15560/3.3.204

Marinone, S.G. (1982). Transporte litoral sobre las barras de Guerrero Negro y Ojo de Liebre. Ciencias Marinas, 8(1), 20 29.

https://doi.org/10.7773/cm.v8i1.384 
Miller, D.J., Lea, R.N. (1972). Guide to the coastal marine fishes of California. California Department of Fish and Game, Fish Bulletin, 157, 235p.

Moser, H.G., Charter, L.R., Smith, P.E., Ambrose, D.A., Charter, S.R., Meyer, C.A., Sandknop, E.M., Watson, W. (1993). Distributional atlas of fish larvae and eggs in the California Current region: taxa with 1000 or more total larvae, 1951 through 1984. CALCOFI Atlas No. 31.233p.

Nelson, J.S. (2006). Fishes of the world, 4th edition. New York, John Wiley \& Sons, 601p. ISBN-13: 978-0471250319. NOAA's El Niño page. National Oceanographic and Atmospheric Administration. (Retrieved from http://www. https://www.climate.gov/enso/ (accessed 08. 10. 2019).

Page, L.M., Espinosa-Pérez, H., Findley, L.T., Gilbert, C.R., Lea, R.N., Mandrak, N.E., Mayden R., Nelson, J.S. (2013). Common and scientific names of fishes from the United States, Canada, and Mexico, 7th edition. Bethesda, MD. American Fisheries Society, Special Publication 34, 243p. ISBN 978-1-934874-31-8

Quiñones-Arreola, M.F. (2003). Comparación del patrón reproductivo del Megapitaria squialida (Sowerby, 1835) en la laguna ojo de liebre, Océano pacifico y en bahía Juncalito, Golfo de California, BCS, México. Instituto Politécnico Nacional, Centro Interdisciplinario de Ciencias Marinas (CICIMAR). Master's thesis, 68p.

Robinson, C.J. (2016). Evolution of the 2014-2015 sea surface temperature warming in the central west coast of Baja California, Mexico, recorded by remote sensing. Geophysical Research Letters, 43, 7066-7071. https://doi.org/10.1002/2016GL069356

Rodríguez-Padilla, I. (2013). Análisis estadístico de la distribución espacial y temporal (2008-2010) de la temperatura y salinidad en la Laguna Ojo de Liebre, Baja California Sur, México., Universidad de Guadalajara. Master's thesis, 71p.

Rosales-Casián, J.A. (1997). Inshore soft-bottom fishes of two coastal lagoons from the Northern Pacific coast of Baja California. CALCOFI Reports, 38, 180-192.

Zamora-Salvador, J.E. (2015). Transporte de sedimentos y evolución morfológica de la barra de laguna Ojo de Liebre, B.C.S., Universidad de Guadalajara. Master's thesis, 65p. 